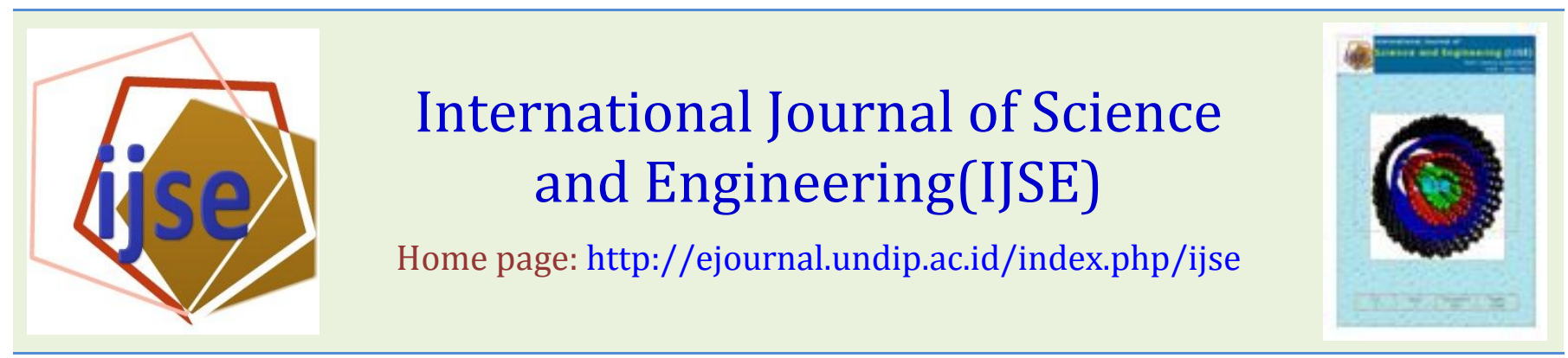

\title{
Soil Erosion Assessment of The Post-Coal Mining Site in Kutai Kartanagera District, East Kalimantan Province
}

\author{
Zulkarnain1), Benny Joy 2), P. Tuhpawana2)., and Indra Prawira3) \\ 1)Agricultural Faculty of Mulawarman University, Kampus Gunung Kelua Samarinda, East Kalimantan 75123 \\ 2)Agricultural Faculty of Padjadjaran University, Jl. Raya Jatinangor, Bandung. West Java \\ 3)Law Faculty of Padjadjaran University, Jl. Raya Jatinangor, Bandung. West Java
}

Email:zulknn@gmail.com

\begin{abstract}
Besides of its positive economic impact, mining activity has negative impacts to the sustainability of community development and livelihoods as mining reclamation can't restore the land condition to its original state. The objective of this study was to determine the main factor that caused soil erosion induced in post-coal mining and defined reclamation activity that caused soil erosion. The observed parameters were site reclamation age of each companies, soil physical properties (density, texture, permeability, organic material and soil structure), rainfall rate, soil chemical properties, land cover and age of re-vegetation, plant cover. Analysis was carried out to determine the magnitude of erosion at each site unit, tolerable erosion and potential erosion level. Adequate reclamation action with good vegetative cover could be seen from erosion magnitude at five year reclamation age i.e. 1.7 ton/ha/ year which lower than tolerable erosion i.e. 5.4 ton/ha/year. While inadequate reclamation action could be seen from erosion magnitude at nine year age of reclamation i.e. 201.1 ton/ha/year ${ }^{1}$ which higher than tolerable erosion i.e. $15.1 \mathrm{ton} / \mathrm{ha} / \mathrm{year} \mathrm{r}^{1}$. The erosion magnitude at the four month of reclamation age was 4.966,3 ton/ha with tolerable erosion was 5.3 ton/ha. The erosion magnitude that occurs in post-mining site was due to soil compaction that lowering soil permeability rate leading to slow growing of cover crop. This condition made the soil wasn't covered from raindrop and water run-off. In order to improve the soil condition of post-mining site into productive land, legume cover crop was recommended to be planted.
\end{abstract}

Keywords: soil erosion, post-coal mining land, reclamation(;)

Submission: May 14, $2014 \quad$ Corrected : June 16, $2014 \quad$ Accepted: September 3, 2014

Doi: 10.12777 ijse.7.2.130-136

[How to cite this article: Zulkarnain, Z., Joy,, B., Tuhpawana, P. and Prawira I. 2014. Soil Erosion Assessment of The Post-Coal Mining Site in Kutai Kartanagera District, East Kalimantan Province, International Journal of Science and Engineering, 7(2),130-136, Doi: 10.12777/ijse.7.2.130-136

\section{INTRODUCTION}

Open cut mining potentially damages the condition of soil itself. Some of those hazardous impacts are soil physical changes, land surface changes, soil ecosystem changes that leads into erosion and sedimentation as well as micro climate changes.

Coal open cut mining is the common method implemented by coal companies in East Kalimantan. This method is done through digging bench that used to create mining site as it required (Coppin and Bradshaw, 1982). Open cut mining is carried out by digging bench, removing and burying the cover layer through back filling of each mining block and adjusting to the mineral deposit deployment (Suhala et al., 1995).

If recovering is inappropriate, the topsoil which has high fertility will be mixed or burned at the lower layer and the sub soil that is less fertile will move into upper layer (Bian Zhengfu et al., 2010). As a result of open cut mining, the soil's carrying capacity becomes low and the soil structure is damaged that potentially leading to erosion (Coppin and Bradshaw, 1982).

Soil erosion is determined by two factors i.e. erosivity and erodibility. Erosivity indicates rainfall intensity to break down soil particle. Erodibility indicates the ability of soil to resist erosion caused by rainfall and water runoff (Arsyad, 2010). In order to maintain the productivity of the soil, erosion that occurs should be lower than the tolerable soil loss (Skidmore, 1982). An assessment to measure erosion hazard of an area is by calculating the maximum soil loss and compared with thick soil solum of each unit area. This assessment is carried out to decide the soil management and soil conservation (Smith et al., 1965).

Reclaimed site is generally less stable as a result of excessive grading that creates high density soil (Ghose, 
1989). This condition causes disruption of root growth, high water runoff and small infiltration rate (Iskandar, 2012). Reclaiming post-coal mining site could reduce erosion and water run-off (Patiung et al., 2011).

Considering the conditions mentioned above, mining activity should minimize their environmental impacts. Sedimentation largely occurs due to erosion that damages the soil. Analysis that provides information concerning the main causes of erosion at post-coal mining site is necessary to carried out.

\section{RESEARCH METHOD}

This research was taken place in several coal mining companies in Kutai Kartanegara district, East Kalimantan province (Indonesia) (fig. 1)..

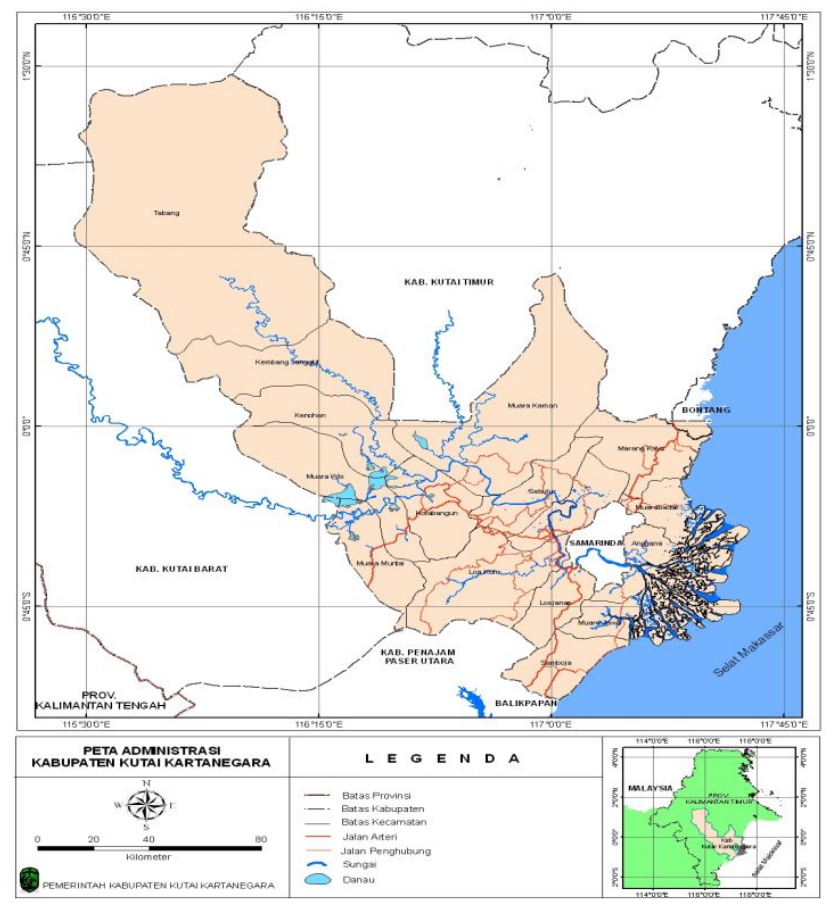

Figure 1. Research location in Kutai Kartanegara district.

Table 1. Geografic Position of coal mining at Kutai Kartanegara district.

\begin{tabular}{lcll}
\hline No & $\begin{array}{c}\text { Location } \\
\text { code }\end{array}$ & \multicolumn{1}{c}{ Latitude } & \multicolumn{1}{c}{ longitude } \\
\hline 1. & $\mathrm{~F}$ & $0^{\circ} 21^{\prime} 42.87^{\prime \prime} \mathrm{LS}$ & \multicolumn{1}{c}{$116^{\circ} 33^{\prime} 48.5^{\prime \prime} \mathrm{BT}$} \\
2. & $\mathrm{D}$ & $00^{\circ} 24^{\prime} 46.00^{\prime \prime} \mathrm{LS}$ & $16^{\circ} 47^{\prime} 37.20 \mathrm{BT}$ \\
3. & $\mathrm{H}$ & - & - \\
4. & $\mathrm{E}$ & - & - \\
5. & $\mathrm{G}$ & $0^{\circ} 20^{\prime} 32.9^{\prime \prime} \mathrm{LS}$ & $117^{\circ} 08^{\prime} 08^{\prime \prime} \mathrm{BT}$ \\
6. & $\mathrm{~A}$ & $0^{\circ} 17^{\prime} 43.22^{\prime} \mathrm{LS}$ & $117^{\circ} 08^{\prime} 11.76^{\prime \prime} \mathrm{BT}$ \\
7. & $\mathrm{~B}$ & - & - \\
8. & $\mathrm{C}$ & - & - \\
9. & $\mathrm{~J}$ & $00^{\circ} 41^{\prime} 26.90^{\prime \prime} \mathrm{LS}$ & $117^{\circ} 15^{\prime} 27.20^{\prime \prime} \mathrm{BT}$ \\
10. & $\mathrm{~K}$ & $00^{\circ} 21^{\prime} 40.4^{\prime \prime} \mathrm{LS}$ & $117^{\circ} 17^{\prime} 12.90^{\prime \prime} \mathrm{BT}$ \\
11. & $\mathrm{I}$ & $00^{\circ} 58^{\prime} 34.4^{\prime \prime} \mathrm{LS}$ & $117^{\circ} 02^{\prime} 58^{\prime \prime} \mathrm{BT}$ \\
\hline
\end{tabular}

The observed parameters were site reclamation age of each companies, soil physical properties (density, texture, permeability, organic material and soil structure), rainfall rate, soil chemical properties, land cover and age of revegetation, plant cover.

To predict the erosion of each land unit, Universal Soil Loss Equation (USLE) developed by Wischmeier and
Smith (1958) was employed in this research (Renard et al., 1997):

$$
\mathrm{A}=\mathrm{R} \times \mathrm{K} \times \mathrm{L} \times \mathrm{S} \times \mathrm{C} \times \mathrm{P}
$$

Whereas:

A = annual soil loss (ton/ha/year)

$\mathrm{R}=$ rainfall erosivity factor $(\mathrm{mj} . \mathrm{cm} / \mathrm{ha} / \mathrm{h} /$ year $)$

$\mathrm{K}=$ soil erodibility factor (ton.ha.h/ha/mj.cm)

$\mathrm{L}=$ slope length factor

$\mathrm{S}=$ slope steepness factor

$\mathrm{C}=$ cropping management factor

$\mathrm{P}=$ soil conservation factor

Tolerable soil loss was equated using this following formula:

$$
\mathrm{T}=(\mathrm{ESD} / \mathrm{RL})+\mathrm{LPT} \times \mathrm{BD} \times 10
$$

Wheras:

$\mathrm{T}=$ tolerable soil loss (ton/ha/year)

ESD =depth equivalent which derived from multiplication of soil effective depth with depth factor ( $\mathrm{mm}$ )

$\mathrm{RL}=$ land use age

$\mathrm{LPT}=$ soil formation rate

$\mathrm{BD}=$ bulk Density $(\mathrm{gr} / \mathrm{cm} 3)$.

Potential soil loss was determined from comparison between actual soil loss (A) and tolerable soil loss (T) as written as follows:

$\mathrm{TBE}=\mathrm{A} / \mathrm{T}$

Table 2. Potential soil erosion (Hammer, 1981)

\begin{tabular}{cc}
\hline Value & Class \\
\hline$<1.0$ & Low \\
$1.01-4.00$ & Moderate \\
$4.01-10.00$ & High \\
$>10.00$ & Severe \\
\hline
\end{tabular}

\section{RESULT AND DISCUSSION}

The process of open cut mining involves land clearing, striping and pilling up the land cover, coal digging, restoring or covering the open mine pit through site reclamation. Site reclamation should be performed immediately otherwise potentially leading to problems such as delay in managing soil excavation and overburden which can cause severe erosion and sedimentation. In residential environment, this activity may cause pollution that disturb public convenience.

Erosion can be one indicator in measuring mine reclamation process. The increasing of eroded soil will turn into depletion of fertile soil availability. In order to maintain the sustainability of soil productivity, the level of soil loss should be lower than tolerable soil loss. If erosion is lower than tolerable soil loss then it can be said that reclamation is successfully performed in maintaining the sustainability of soil productivity (Bradshaw, 1983).

Soil erosion occurred at post-mining site was observed at two conditions i.e. the condition of reclaimed site and erosion that occurs after reclamation. This observation was carried out at several coal companies in Kutai Kartanegara districts.

The first reclamation activity after completing mining process is covering the mining pit with overburden soil. This activity is important which aims to restoring the overburden into its original place. Activity of restoring overburden also aims to restore the soil into their original 
layer position (lower soil with sub soil and upper layer with top soil) and the thickness of soil solum (soil at the surface layer up to before rocky layer) with minimum thickness was $150 \mathrm{~cm}$ and or similar to its previous thickness before mining process. The thickness of the soil solum was determined to ensure the long term growth of plants and provide stability of root.

The observation showed that restored thickness of soil solum ranged from $10-80 \mathrm{~cm}$ which indicated that reclamation was occurred at thin or shallow solum (Table 3). Only in E and I location that had solum thickness reached up to $80 \mathrm{~cm}$. However, restoring activity at these locations didn't meet the reclamation codes which stated that that the amount of restored soil must similar to the amount of soil that had been removed. The shallow of soil solum is a factor that inhibits the growth of certain plant especially perennial plant and or grass or shrubs. This condition will result negative impact to the environment and other aspect of life considering the large of area that had been and will be opened for coal mining.

Several factors caused the thinness of the restored soil solum. Two of them were the absence of regulatory written in EIA (Environmental Impact Analysis, (Analisis mengenai dampak lingkungan) and the mining pit was turned into a pond due to the depth of the pit.

The condition of this shallow soil solum couldn't sustain plant productivity when the post-mining site was used for agricultural or forestry activities. This area was also vulnerable to erosion creating to a critical land.
Table 3. Soil Solum Depth after Reclamation

\begin{tabular}{|c|c|c|c|c|}
\hline No & Sub-district & $\begin{array}{c}\text { Company } \\
\text { Code }\end{array}$ & $\begin{array}{l}\text { Reclamation } \\
\text { age (years) }\end{array}$ & $\begin{array}{c}\text { Solum } \\
\text { depth } \\
(\mathrm{cm})\end{array}$ \\
\hline \multirow[t]{2}{*}{1} & Tenggarong Seberang & $\mathrm{A} 1$ & 5 & 30 \\
\hline & & A2 & 2 & 15 \\
\hline 2 & Tenggarong Seberang & $\mathrm{B}$ & 5 & 25 \\
\hline 3 & Tenggarong Seberang & $\mathrm{C}$ & 1 & 10 \\
\hline \multirow[t]{2}{*}{4} & Tenggarong & D1 & 15 & 52 \\
\hline & & D2 & 1 & 56 \\
\hline \multirow[t]{2}{*}{5} & Tenggarong & E1 & 11 & 80 \\
\hline & & E2 & 2 & 25 \\
\hline \multirow[t]{2}{*}{6} & Kota Bangun & $\mathrm{F} 1$ & 9 & 70 \\
\hline & & $\mathrm{F} 2$ & 2 & 50 \\
\hline \multirow[t]{2}{*}{7} & Sebulu & G1 & 3 & 48 \\
\hline & & G2 & 0.25 & 25 \\
\hline 8 & Muara Jawa & $\mathrm{H}$ & 0.08 & 10 \\
\hline 9 & Samboja & I & 0.17 & 80 \\
\hline \multirow[t]{2}{*}{10} & Muara Badak & J1 & 0.33 & 55 \\
\hline & & $\mathrm{J} 2$ & 0.08 & 15 \\
\hline 11 & Muara Badak & $\mathrm{K}$ & 0.33 & 25 \\
\hline
\end{tabular}

Returning soil physical properties is important to guarantee the soil stability for plant growth. Observation showed that soil layer was not restored to its original layer. Soil was only returned into one layer with one texture class. Thus, thin layer couldn't provide adequate stability for long-term plant growth (Table 4).

Table 4. Soil Physical Properties After Reclamation.

\begin{tabular}{|c|c|c|c|c|c|c|c|}
\hline \multirow[b]{2}{*}{ No } & \multirow[b]{2}{*}{ Sub-district } & \multirow[b]{2}{*}{ Code } & \multirow{2}{*}{$\begin{array}{l}\text { Reclamation } \\
\text { age (year) }\end{array}$} & \multirow{2}{*}{$\begin{array}{c}\mathrm{BD} \\
\left(\mathrm{g} / \mathrm{cm}^{3}\right)\end{array}$} & \multicolumn{2}{|c|}{ Permeability } & \multirow[b]{2}{*}{ Texture } \\
\hline & & & & & $\begin{array}{c}\text { Value } \\
(\mathrm{cm} / \mathrm{jam})\end{array}$ & Status & \\
\hline \multirow[t]{2}{*}{1} & \multirow[t]{2}{*}{ Tenggarong Seberang } & A1 & 5 & 1.03 & 8.429 & $\mathrm{C}$ & $\mathrm{L}=$ clay \\
\hline & & $\mathrm{A} 2$ & 2 & 0.99 & 0.079 & $\mathrm{~L}$ & $\begin{array}{l}\text { SCL= sandy clay } \\
\text { loam }\end{array}$ \\
\hline 2 & Tenggarong Seberang & B & 5 & 1.14 & 0.078 & $\mathrm{~L}$ & $\mathrm{SL}=$ sandy clay \\
\hline 3 & Tenggarong Seberang & $\mathrm{C}$ & 1 & 0.80 & 0.247 & $\mathrm{~L}$ & $\mathrm{CL}=$ clay loam \\
\hline \multirow[t]{2}{*}{4} & \multirow[t]{2}{*}{ Tenggarong } & D1 & 15 & 0.81 & 21.135 & $\mathrm{C}$ & $\mathrm{CL}=$ clay loam \\
\hline & & D2 & 1 & 0.90 & 6.621 & $\mathrm{~S}$ & $\mathrm{SL}=$ sandy clay \\
\hline \multirow[t]{2}{*}{5} & \multirow[t]{2}{*}{ Tenggarong } & E1 & 11 & 0.88 & 0.018 & $\mathrm{~L}$ & CL= clay loam \\
\hline & & E2 & 2 & 1.02 & 1.430 & $\mathrm{C}$ & $\mathrm{CL}=$ clay loam \\
\hline \multirow[t]{2}{*}{6} & \multirow[t]{2}{*}{ Kota Bangun } & F1 & 9 & 1.23 & 0.119 & $\mathrm{~L}$ & $\mathrm{CL}=$ clay loam \\
\hline & & $\mathrm{F} 2$ & 2 & 1.38 & 0.079 & $\mathrm{~L}$ & $\mathrm{SL}=$ sandy clay \\
\hline \multirow[t]{2}{*}{7} & \multirow[t]{2}{*}{ Sebulu } & G1 & 3 & 0.96 & 0.020 & $\mathrm{~L}$ & $\mathrm{CL}=$ clay loam \\
\hline & & $\mathrm{G} 2$ & 0.25 & 1.06 & 0.004 & $\mathrm{~L}$ & SiL= silty clay \\
\hline 8 & Muara Jawa & $\mathrm{H}$ & 0.08 & 1.19 & 0.027 & $\mathrm{~L}$ & $\mathrm{SL}=$ sandy clay \\
\hline 9 & Samboja & I & 0.17 & 1.08 & 0.223 & $\mathrm{~L}$ & $\mathrm{CL}=$ clay loam \\
\hline \multirow[t]{2}{*}{10} & Muara Badak & $\mathrm{J} 1$ & 0.33 & 0.70 & 0.002 & $\mathrm{~L}$ & $\mathrm{CL}=$ clay loam \\
\hline & & $\mathrm{J} 2$ & 0.88 & 0.70 & 0.005 & $\mathrm{~L}$ & $\mathrm{CL}=$ clay loam \\
\hline 11 & Muara Badak & $\mathrm{K}$ & 0.33 & 1.21 & 0.002 & $\mathrm{~L}$ & $\mathrm{~L}=$ clay \\
\hline
\end{tabular}

Source: Primary data (2010).

The above data shows that the physical property of the soil used to recover the mining pit was clay and its variations. Clay loam texture was dominated the soil followed by sandy loam texture (Dexter, 1988). Soil with more clay content will be easily attached and has less porous space leading to slower permeability as shown in general mining soil condition of this research area (Hillel, 1998).

Clay texture with loam content causes slower permeability in post-mining site which describes the water run-off of the land. The water run-off becomes bigger along the slower movement of the soil permeability that leads to higher erosion.

Research resulted by Patiun et al. (2011), showed that until the reclamation age of 15 years with acacia vegetation, the soil permeability is still low i.e. $12.03 \mathrm{~cm} /$ hour at $0-15 \mathrm{~cm}$ depth and $2.49 \mathrm{~cm} /$ hour at $15-30 \mathrm{~cm}$ depth. This indicates that the changes in soil compaction affected the soil permeability up to 15 year age of reclamation. 
Negative condition was shown by bulk density analysis which generally had more than one indicating dense soil. This condition makes root difficult to penetrate into the soil and decreasing air and aeration. This finding was consistent to the result of Patiung et al. (2011) who stated that bulk density of reclamation land at 15 year of age is 1.47 at $0-15 \mathrm{~cm}$ depth and 1.56 at $15-30 \mathrm{~cm}$ depth. This condition significantly affected the root growth and plant yield.

Research also found low bulk density at several reclamation sites. Unfortunately, these lands also in shallow solum and the soil are mixed with residual coal, gravel and soil concretions. Therefore, low value of bulk density existed in these reclamation sites was not because of high organic material content. Therefore, it didn't give benefit for plant growth.

In term of bulk density, the soil didn't have adequate holding power for perennial plants and the restored soil was porous that vulnerable to erosion.

According to rating fertility of top soil (Table 5) that based on soil fertility criterion, the soil fertility level of each observation locations was determined based on Cation Exchange Capacity (CEC), Base Saturation (BS), P availability, $\mathrm{K}$ availability and organic matter. Overall, soil fertility of the post-coal mining sites in Kutai Kartanegera district was low.

Table 5. Soil Physical Properties After Reclamation.

\begin{tabular}{|c|c|c|c|c|c|c|c|c|}
\hline Sub-district & $\begin{array}{c}\text { Location } \\
\text { code }\end{array}$ & $\begin{array}{c}\text { Reclamation } \\
\text { age (year) }\end{array}$ & CEC & BS & $\mathrm{P}_{2} \mathrm{O}_{5}$ & $\mathrm{~K}_{2} \mathrm{O}$ & C-organic & Fertility status \\
\hline \multirow{4}{*}{$\begin{array}{l}\text { Tenggarong } \\
\text { Seberang }\end{array}$} & \multirow{2}{*}{$\mathrm{A}$} & 2 & $\mathrm{~S}$ & ST & SR & $\mathrm{T}$ & SR & $\mathrm{R}$ \\
\hline & & 5 & S & ST & SR & ST & $\mathrm{R}$ & $\mathrm{R}$ \\
\hline & B & 5 & $\mathrm{R}$ & $\mathrm{T}$ & SR & ST & $\mathrm{R}$ & $\mathrm{R}$ \\
\hline & $\mathrm{C}$ & 1 & S & S & SR & ST & $\mathrm{R}$ & $\mathrm{R}$ \\
\hline \multirow{4}{*}{ Tenggarong } & \multirow[b]{2}{*}{ D } & 1 & S & SR & $\mathrm{R}$ & $\mathrm{R}$ & SR & $\mathrm{R}$ \\
\hline & & 15 & $\mathrm{R}$ & $\mathrm{R}$ & SR & S & $\mathrm{T}$ & $\mathrm{R}$ \\
\hline & \multirow{2}{*}{ E } & 2 & $\mathrm{R}$ & ST & SR & ST & $\mathrm{R}$ & $\mathrm{R}$ \\
\hline & & 11 & S & $\mathrm{T}$ & SR & $\mathrm{T}$ & $\mathrm{R}$ & $\mathrm{R}$ \\
\hline \multirow{2}{*}{ Kota Bangun } & \multirow{2}{*}{$F$} & 2 & $\mathrm{R}$ & SR & SR & $\mathrm{R}$ & SR & $\mathrm{R}$ \\
\hline & & 9 & S & $\mathrm{R}$ & SR & S & $\mathrm{R}$ & $\mathrm{R}$ \\
\hline \multirow{2}{*}{ Sebulu } & \multirow{2}{*}{$\mathrm{G}$} & $0.25^{*}$ & $S$ & ST & SR & SR & $\mathrm{T}$ & $\mathrm{R}$ \\
\hline & & $0.17^{*}$ & $\mathrm{R}$ & $\mathrm{T}$ & SR & $\mathrm{T}$ & SR & $\mathrm{R}$ \\
\hline Muara Jawa & $\mathrm{H}$ & $0.08^{*}$ & $\mathrm{R}$ & $\mathrm{R}$ & SR & S & $\mathrm{R}$ & $\mathrm{R}$ \\
\hline Samboja & I & $0.17^{*}$ & $\mathrm{R}$ & $\mathrm{T}$ & SR & $\mathrm{T}$ & $\mathrm{T}$ & $\mathrm{R}$ \\
\hline \multirow{3}{*}{ Muara Badak } & \multirow{2}{*}{$\mathrm{J}$} & $0.08^{*}$ & $\mathrm{R}$ & $\mathrm{S}$ & SR & $\mathrm{T}$ & SR & $\mathrm{R}$ \\
\hline & & $0.33^{*}$ & $\mathrm{R}$ & S & SR & $\mathrm{T}$ & S & $\mathrm{R}$ \\
\hline & $\mathrm{K}$ & $0.33^{*}$ & $\mathrm{R}$ & SR & SR & S & $\mathrm{R}$ & $\mathrm{R}$ \\
\hline
\end{tabular}

Source: Primary data analysis (2010)

Script: $\mathrm{ST}=$ very high, $\mathrm{T}=$ high, $\mathrm{S}=$ moderate, $\mathrm{R}=$ low $\mathrm{SR}=$ very low.
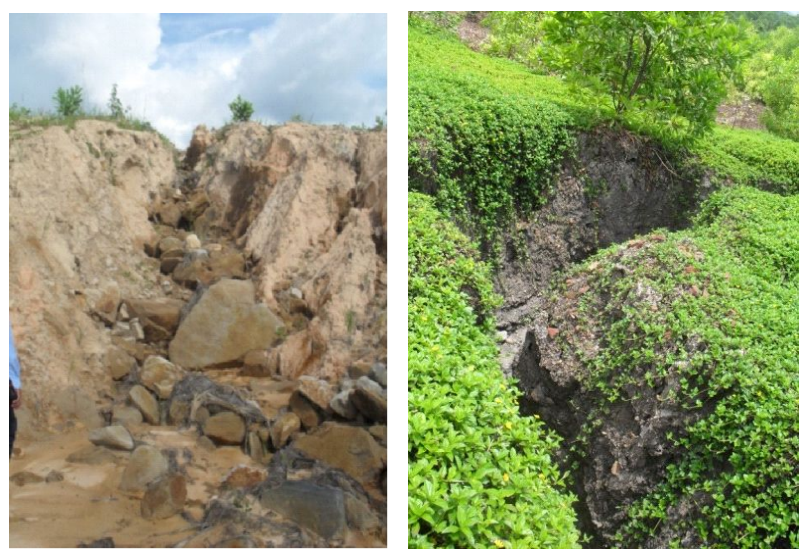

Figure 2. Soil erosion at post coal mining site in Kutai Kartanegara district

A soil condition with low fertility level was caused by the mixing of all soil layers from top to the bottom layer. Separation process of top soil carried out by coal companies was not the actual top layer $\left(\mathrm{A}_{0}\right.$ atau $\mathrm{A}_{1}$ layer $)$. A process of removing soil using bulldozer was not able to push or remove $A_{0}$ atau $A_{1}$ layer which located at $0-10 \mathrm{~cm}$ depth. The capability of bulldozer is to remove soil layer at 2-50 cm depth. However, top soil at ultisol soil in East Kalimantan is $5-10 \mathrm{~cm}$ depth which generally occurs in primary forest and rarely found in secondary forest or shrub area.

Coal companies perform revegetation by planting monoculture hard wood tree. However, replanting process which carried out by company was not in accordance with the reclamation rules. Company didn't plant cover crop prior planting perennial tree in order to provide open land area. This caused erosion and loss of soil nutrients.

Moreover, there were companies that didn't carry out revegetation. The land was remained open and forced to naturally recovered. Pioneer vegetation such as reeds still can grow in this land with high tolerance to limited condition.

Acacia (accacia mangium) that were planted during revegetation grew well. Table 6 shows detail observation result.

Table 6. Trunk Circumference and Height of Acacia (A.mangium) Tree in Reclaimed Site

\begin{tabular}{|c|c|c|c|c|}
\hline $\begin{array}{l}\text { Location } \\
\text { code }\end{array}$ & $\begin{array}{c}\text { Reclamation } \\
\text { age (year) }\end{array}$ & Plant & $\begin{array}{c}\text { Trunk } \\
\text { Circumference } \\
(\mathrm{cm}) \\
\end{array}$ & $\begin{array}{l}\text { Height } \\
(\mathrm{cm})\end{array}$ \\
\hline $\mathrm{A}$ & 2 & Acacia & 38.25 & 530.00 \\
\hline B & 5 & Acacia & 63.70 & $1,200.00$ \\
\hline E & 2 & Acacia & 7.86 & 201.43 \\
\hline
\end{tabular}


At the second year of reclamation age, Acacia tree planted at several locations of post-mining site used for revegetation had trunk circumference of 38.25-7.86 cm and tree height of $201.43-530.00 \mathrm{~cm}$. At the fifth year age, the trunk circumference and tree height became $63.7 \mathrm{~cm}$ and $1200.00 \mathrm{~cm}$. This indicated that acacia planted at post-mining site could have similar growth with those planted in normal land. Acacia at third year, the density was 1,838 trees, trunk circumference was $7.25 \mathrm{~cm}$ and tree height was $7.33 \mathrm{~m}$. While at the fifth year, the density was 475 trees, tree diameter was $16.03 \mathrm{~cm}$ and height was $15.16 \mathrm{~m}$. That data shows that acacia can be used for revegetation plant at post-coal mining in Kutai Kartanegara district.

Acacia (A. mangium) was selected by coal companies due to several factors. Acacia can grow in a limited growth environment such as the presence of gravels, residual coal, soil concretion and shallow solum (low fertility level). However, acacia was not suggested for revegetation purpose as the leaf contains high $\mathrm{C} / \mathrm{N}$ ratio leading too difficult to decay and plant canopy is narrow that can't cover the soil from raindrop. This can be seen from low fertility level, ground cover vegetation was small and rare, and no organic matter found at top soil.

Sengon (Paraserianthes falcataria) that was planted at post-coal mining had trunk circumference of $2.69-7.20 \mathrm{~cm}$ and height of $57.83-425.00 \mathrm{~cm}$ at the second and first year (Table. 7). At the fifth year, the trunk circumference and height was $58.55 \mathrm{~cm}$ and $1,535.00 \mathrm{~cm}$, respectively. At eleventh year, the trunk circumference and height became $103.83 \mathrm{~cm}$ and $1,233.33 \mathrm{~cm}$, respectively. In this land, the trunk circumference of sengon was four times higher than those planted in normal land. Therefore, it can be concluded that sengon was more appropriate as revegetation plant in post-coal mining land.

Table 7. Trunk Circumference and Height of Sengon (Paraserianthes falcataria) in Reclaimed Site

\begin{tabular}{cccrr}
\hline $\begin{array}{c}\text { Location } \\
\text { code }\end{array}$ & $\begin{array}{c}\text { Reclamation } \\
\text { age (year) }\end{array}$ & Plant & $\begin{array}{c}\text { Trunk } \\
\text { Circumference } \\
\text { (cm) }\end{array}$ & \multicolumn{1}{c}{$\begin{array}{c}\text { Height } \\
(\mathrm{cm})\end{array}$} \\
\hline A & 5 & Sengon & 58.55 & $1,535.00$ \\
C & 1 & Sengon & 2.69 & 425.00 \\
E & 11 & Sengon & 103.83 & $1,233.33$ \\
F & 2 & Sengon & 7.20 & 57.83 \\
G & 3 & Sengon & 16.35 & 367.50 \\
\hline \multicolumn{4}{l}{ Source: Primary data (2010) }
\end{tabular}

An exception occurs at the third year of revegetation when the trunk circumference and height only turned into $16.35 \mathrm{~cm}$ and $367.50 \mathrm{~cm}$ which quite far from normal condition. This could be due to inadequate solum for the growing of Sengon. Sengon (Paraserianthes falcataria) was selected as revegetation plant due to its capacity to increase soil fertility as it has low $\mathrm{C} / \mathrm{N}$ ratio and wide canopy. According from the observation result, the land which planted by sengon has organic matter layer, high fertility and ground cover vegetation was fertile and large. Moreover, sengon has high economic value as the trunk of sengon can be utilized for manufacturing paper.

Rubber (Havea brasiliensis) that was planted at postcoal mining did not show good result. The height was only tree meters in the third year. The height of rubber (Havea brasiliensis) tree at 2-3 year is about $3.5 \mathrm{~m}$. This could be due to shallow solum and low fertility level that could not support the growth of rubber tree.

Erosion that occurred at reclaimed site was higher than the tolerable soil loss (Table 8). Concerning to the shallow solum of the land, this condition was very dangerous as the soil was continually eroded and loss within short time.

The research showed that erosion magnitude during the first month of reclamation age was $4.810,4$ ton ha- ${ }^{-1}$ while other companies showed that until four month the erosion magnitude was 4,966.3 ton/ha. This indicated that reclamation carried out by several companies was very bad. Meanwhile, erosion magnitude could only be reduced by 1.9 ton/ha/year for companies who had good reclamation program. Inadequate reclamation action could be seen from erosion magnitude at nine year age of reclamation i.e. 201.1 ton/ha/year. Adequate reclamation action with good vegetative cover could be seen from erosion magnitude at five year reclamation age i.e. 1.7 ton/ha/ year.

Land cover by vegetation significantly influences the kinetic force breakdown of raindrop leading to reducing the soil particle breakdown. Nevertheless, water run-off also affects the sheet erosion. Therefore, vegetation capacity to restrain water is very important. This condition can be seen in land with many reeds and shrubs had greater erosion magnitude compared to forest land.

The slope of soil significantly affects the erosion magnitude. The greater the slope, the greater erosion will occur. This condition is due to water flow rate at steep slope. Besides of the slope steepness, erosion magnitude is determined by the length of the slope. The longer the slope, more soil will be eroded and carried by water (Yamani, 2012).

Correlation between soil erosion and soil density influences the erosion process. Erosion magnitude becomes higher along the denser of the soil. If the density of the soil increases, the soil pores becomes smaller then soil permeability becomes slower. This condition causes the increasing of water run-off leading to higher erosion. 
Table 8. Soil Loss Magnitude and Tolerable Soil Loss at Reclaimed Site

\begin{tabular}{|c|c|c|c|c|c|c|}
\hline No & Sub-district & Code & $\begin{array}{l}\text { Reclamation } \\
\text { age (thn) }\end{array}$ & $\begin{array}{l}\text { Soil Solum Depth } \\
\qquad(\mathrm{cm})\end{array}$ & $\begin{array}{c}\text { Soil Loss } \\
\text { (ton/ha/thn) }\end{array}$ & $\begin{array}{l}\text { Tolerable Soil Loss } \\
\text { (ton/ha/thn) }\end{array}$ \\
\hline 1 & $\begin{array}{l}\text { Tenggarong } \\
\text { Seberang }\end{array}$ & $\mathrm{A}_{1}$ & 5 & 30 & 1.7 & 5.4 \\
\hline 2 & $\begin{array}{l}\text { Tenggarong } \\
\text { Seberang }\end{array}$ & $\mathrm{A}_{2}$ & 2 & 15 & 119.3 & 2.6 \\
\hline 3 & $\begin{array}{l}\text { Tenggarong } \\
\text { Seberang }\end{array}$ & B & 5 & 25 & 341.0 & 5.0 \\
\hline 4 & $\begin{array}{l}\text { Tenggarong } \\
\text { Seberang }\end{array}$ & $\mathrm{C}$ & 1 & 10 & 1.9 & 1.4 \\
\hline 5 & Tenggarong & $\mathrm{D}_{1}$ & 15 & 52 & 2.7 & 7.4 \\
\hline 6 & & $\mathrm{D}_{2}$ & 1 & 56 & 250.6 & 8.8 \\
\hline 7 & Tenggarong & $\mathrm{E}_{1}$ & 11 & 80 & 2.1 & 12.3 \\
\hline 8 & & $\mathrm{E}_{2}$ & 2 & 25 & 1371.5 & 4.5 \\
\hline 9 & Kota Bangun & $\mathrm{F}_{1}$ & 9 & 70 & 201.1 & 15.1 \\
\hline 10 & & $\mathrm{~F}_{2}$ & 2 & 50 & 481.6 & 12.0 \\
\hline 11 & Sebulu & $\mathrm{G}_{1}$ & 3 & 48 & 650.9 & 8.1 \\
\hline 12 & & $\mathrm{G}_{2}$ & 0.25 & 25 & $2,860.0$ & 4.7 \\
\hline 13 & Muara Jawa & $\mathrm{H}$ & 0.08 & 10 & 314.9 & 2.1 \\
\hline 14 & Samboja & I & 0.17 & 80 & 195.2 & 15.1 \\
\hline 15 & Muara Badak & $\mathrm{J}_{1}$ & 0.33 & 55 & 36.5 & 6.8 \\
\hline 16 & & $\mathrm{~J}_{2}$ & 0.08 & 15 & $4,810.4$ & 1.8 \\
\hline 17 & Muara Badak & $\mathrm{K}$ & 0.33 & 25 & $4,966.3$ & 5.3 \\
\hline
\end{tabular}

Source: Primary Data (2010)

Soil erosion can be an indicator of successful post-coal mining reclamation. Level of erosion indicates the level of success in restoring physical, chemical and organic material into its original state and also indicates the level of success of revegetation process.

Data mentioned above indicated the unsuccessful reclamation process as shown by restoring activity of physical characteristic with soil solum thickness was less than $1 \mathrm{~m}$. Other data also mentioned that soil chemical properties hasn't provided good result leading to actual erosion was higher than tolerable erosion.

Some factors in open cut mining activity that should be noticed are land clearing and placing the overburden. These factors should be carefully done to prevent higher erosion. Restoring and rearranging overburden are also important.

Mining site reclamation is a process of restoring soil condition to support plant productivity. The main important thing is that site reclamation is done to prevent erosion, sedimentation, landslide and others that endanger people at surrounding mining area.

Planting cover crop with high growing rate is a good action. However, companies only plant perennial crop and thought that planting cover crop isn't necessary to be done. They thought that the success of reclamation is indicated by the growing of forest tree such as sengon (Paraserianthes falcataria) and acacia (Accacia mangium). The benefit of cover crop with high growing rate is its higher ability to prevent soil from erosion and provide more soil organic material compared to perennial crop which need longer time to cover soil surface.

In order to maintain sustainable land productivity, erosion should be lower than tolerable erosion. In term of soil conservation, reclamation is said to be success if actual erosion is lower than tolerable erosion.

Some factors that caused erosion occurred in postmining land were:
1. Soil structure had already damaged during land clearing;

2. Restoring soil solum was carried out without considering the soil stability;

3. Land remained open during revegetation activity; and

4. Soil wasn't covered when plant canopy was able providing shelter for soil.

\section{CONCLUSION}

This research concluded that post-coal mining reclamation wasn't performed in consecutive process. This could be seen from the restored soil solum during reclamation process was $10-80 \mathrm{~cm}$. In the beginning of reclamation process, erosion magnitude at the fourth month was $4,966.3$ ton/ha with tolerable soil loss was 5.3 ton/ha. Bad reclamation process was indicated by erosion magnitude at the ninth month which was 201.1 ton/ha/year with tolerable soil loss was 15.1 ton ha/year.

Erosion that occurred in post-coal mining was soil compaction that leads to slower soil permeability and slower cover crop growing. This condition made soil was eroded from raindrop and water run-off.

Stabilization on physical and chemical soil condition through LCC planting and organic matter should be carried out prior revegetation using perennial and or forest plants.

\section{REFERENCES}

[1] Arsyad, S. 2010. Konservasi Tanah dan Air. Edisi Kedua. IPB Pres. Bogor.

[2] Bian Zhengfu, Inyang Hilary I, Daniels John L, Otto Frank, Struthers Sue. 2010. Environmental issues from coal mining and their solutions. Mining Science and Technology 20: 0215-0223

[3] Bradshaw A D. 1983. The reconstruction of ecosystems. Journal of Appl Ecol (20): 1-17.

[4] Coppin, N. J., and Bradshaw, A. D. 1982. The establishment of vegetation in quarries and open-pit non-metal mines. Mining Journal Books, London, 112 p. 
[5] Dexter, A.R. 1988. Advances in the characterization of soil structure. Soil and Tillage Research 11: 199-238.

[6] Friend, J. A. 1992. Achieving soil sustainability. J. Soil Wat. Cons., Ankeny 47: 156-157.

[7] Ghose, M.K. 1989. Land reclamation and protection of environment from the effect of coal mining operation. Mine technology 10 (5): 3539.

[8] Hillel D. 1998. Environmental soil physics. Academic Press. New York.

[9] Iskandar, Suwardi, Suryaningtyas and D. Tjayandari. 2012. Post mining land reclamation and its problem concerned soil properties solution. Pusat Studi Reklamasi Tambang, LPPM-IPB. Disampaikan dalam seminar Nasional topik khusus "Teknologi Pemupukan dan Pemulihan Lahan terdegradasi". Bogor 29-30 Juni.

[10] Patiung, O., N. Sinukaban, S. D. Tarigan, and D. Darusman. 2011. Pengaruh The effect of time post coal mining reclamation on the soil water function. J. Hidrolitan 2 (2): 60-73.

[11] Qian M G, Xu J L, Miao X X. 2003. Green technique in coal mining. Journal of China University of Mining \& Technology 32 (4): 343348.
[12] Renard, K. G.; Foster, G. R.; Weesies, G. A.; McCool, D. K.; Yoder, D. C. 1997. Predicting soil erosion by water: a guide to conservation planning with the Revised Universal Soil Loss Equation (RUSLE). Agriculture Handbook. Washington. 384 pp.

[13] Skidmore, E.L. 1982. Soil loss tolerance. In Determinants of soil loss tolerance. American Society Agronomy.

[14] Smith, R. M, Stamey, and Wiliam L. 1965. Determining the range of tolerable erosion. Soil Science, 100 (6): 414-424.

[15] Suhala, S, A. F. Yoesoef dan Muta'alim. 1995. Indonesian Mining Technology. Pusat Penelitlan dan Pengembangan Teknologi Mineral, Direktorat Jenderal Pertambangan Umum Departemen Pertambangan dan Energi. Jakarta.

[16] Yamani Ahmad. 2012. The amount Erosion Study On Coal Mine Reclamation area in PT. Arutmin Indonesia, New Town District. Jurnal Hutan Tropis. 13 (1): 46-54. 